УДК 159.9:925

DOI: https://doi.org/10.35619/prap_rv.vi12.67

\title{
ПСИХОЛОГІЧНІ ОСОБЛИВОСТІ КОРЕКЦІЇ ПСИХОМОТОРНИХ РОЗЛАДІВ У ХВОРИХ ІЗ ІШЕМІЧНИМ ІНСУЛЬТОМ
}

В статті описано соматичні розлади, які мають місие у випадку виконання рухів при ішемічному інсульті. Схарактеризовано розлади програмування управління психомоторною діяльністю. Описано розлади координації виконання психомоторної діяльності. Виокремлено психологічні особливості корекиії психомоторних розладів у хворих з ішемічним інсультом. Запропоновано психологічні принципи формування загальних компенсаторних реакцій пацієнта у випадку проведення фізичної реабілітаиї хворих з ішемічним інсультом, а саме: 1) принцип актуалізації дефекту; 2) принции прогресивної мобілізації компенсаторних механізмів психомоторної діяльності; 3) принцип безперервного зворотного концентрування компенсаторних механізмів психіки особистості; 4) принцип санкціонування компенсаторних механізмів психіки особистості; 5) принцип відносної стійкості компенсаторних механізмів психіки особистості.

Ключові слова: фізична реабілітачія, ішемічний інсульт, управління психомоторною діяльністю, компенсаторні реакиії, компенсаторні механізми, корекиія психомоторних розладів.

В статье описаны соматические расстройства, которые имеют место в случае выполнения паииентом разных движений при ишемическом инсульте. Дана характеристика расстройствам, связанным с программированием управлением психомоторной деятельностью. Описаньы расстройства координации выполнения психомоторной деятельности. Выделены психологические особенности коррекции реабилитологом психомоторных расстройств у больных с ишемическим инсультом. Предложены психологические принципы формирования общии компенсаторных реакций пациента в случае проведения физической реабилитаџии больных с ишемическим инсультом, а именно: 1) принции актуализации дефекта; 2) принции прогрессивной мобилизации компенсаторных механизмов психомоторной деятельности; 3) принцип непрерывного обратного конщентрирования компенсаторных механизмов психики личности; 4) принцип санкциионирования компенсаторных механизмов психики личности; 5) принщип относительной устойчивости компенсаторных механизмов психики личности.

Ключевые слова: физическая реабилитаиия, ишемический инсульт, управление психомоторной деятельностью, компенсаторные реакиии, компенсаторные механизмы, коррекиия психомоторных расстройств.

Постановка проблеми. Суттєве розповсюдження судинних захворювань головного мозку, що є однією з базових причин інвалідизації і смертності, робить їх однією з найбільш актуальних проблем сучасної неврології України. Захворюваність на ішемічний інсульт в Україні становить 390 на 100000 населення. У Києві за даними Служби швидкої допомоги останніми роками щодня реєструються 50-60 інсультів. При цьому, інвалідизація після інсульту складає 3,2\% випадків на 10 000 населення, до свого основного місця роботи повертається не більше 17,2\% працюючих, а повною мірою фізична реабілітація, за соціологічними даними, досягається лише у $12 \%$ випадків [3].

Аналіз останніх досліджень i публікацій. Найбільш частим i тяжким наслідком церебрального ішемічного інсульту $\epsilon$ розлади рухової функції особистості. Характерним $\epsilon$ поліморфізм рухових порушень у хворих на церебральний ішемічний інсульт. При цьому загальним для хворих $є$ тільки випадання або порушення довільних рухів (виникнення геміпарезу або геміплезії). Інші клінічні симптоми $є$ великою мірою варіабельними і залежать певною мірою від розмірів ділянки ураження, іiі локалізації та ін. За оцінками різних авторів, стійкі розлади рухової функції спостерігаються також в перші дні після захворювання у 70-80\% хворих, які пережили ішемічний інсульт [5].

Розлади довільних рухів при ішемічному інсульті можна розглядати як результат неузгодження складних рухових програм, що забезпечують довільну моторику індивіда. Реалізація таких програм пов'язана, передусім, із функціонуванням складних багатофункціональних систем, в яких провідна роль належить центральному руховому нейрону, що має численні зв'язки в субкортикальних утвореннях, зокрема, - із ретикулярною формацією стовбура головного мозку.

За умов спроби класифікувати моторні (рухові) розлади, що виникають у хворих 3 порушенням мозкового кровообігу, стає зрозумілим, що будь-який розлад можна схарактеризувати, лише описуючи його в декількох парадигмах. За пропозицією ВООЗ, для опису будь-якого розладу $є$ придатними патофізіологічні ознаки (з англ. - impairments). Моторні розлади можуть бути внаслідок 
патологічних змін у м'язовій, скелетній або нервовій системах. Дані щодо патофізіологічних ознак в багатьох випадках дозволяють лише приблизно передбачити, які моторні функції фактично ще можуть виконуватися. Втрата або обмеження функціональних можливостей називається, за пропозицією ВОO3, disabilities. Труднощі опису моторних розладів, в площині функціональних обмежень, полягає у великій кількості можливостей перевірки цих функцій. За умов церебрально зумовлених розладів часто робилися спроби зробити певний, достатньо чіткий порядок моторних функцій з урахуванням моделей церебрального контролю над рухами людини [4].

Моторні розлади можна розрізняти (за типом їхнього генезу) на первинно-органічні i психогенні рухові розлади. У випадку первинно-органічних рухових розладів патологічні зміни спостерігаються в м'язовій, скелетній або нервовій системах, проте, за умов психогенних рухових розладів наявність такого роду змін довести об'єктивно постає неможливим. Щоб описувати моторні розлади у людини, слід, передусім, знати: а) які функції має сенс розрізняти в рухи процесі їхньої регуляції особистістю; б) в якій формі виявляються розлади цих функцій. Відмінностями, які спостерігаються між розладами, є: а) ініціювання рухів; б) розлади у їхньому виконанні. У випадках виконання рухів розрізняються розлади запрограмованого управління, регулювання та координації тощо.

Головна ознака регуляції рухів - це інтеграція регулювання моторних процесів, за допомогою яких рухи більш-менш безперервно пристосовуються до навколишнього світу та інших автономних процесів, які найчастіше позначаються поняттям «регуляція» за допомогою визначеною людиною психомоторною програмою. Сутність розладів у регуляторних процесах виявляється, передусім, в моторних розладах, які виникають за умов спотворення зворотного зв'язку. Сутність автономних процесів, які є незалежними від сенсорної зворотного зв'язку, що надходить 3 периферії тіла, виявляється в тому, що за умов відсутності зворотного зв'язку (включаючи зворотний зв'язок від органів почуттів, зворотний зв'язок в м'язах і суглобах) можливість руху все ж таки зберігається.

Регуляція руху також полягає в тому, що рух спочатку ніби «перераховується в дистальному відношенні». При виконанні певної дії м'язи мають включитися таким чином, щоб було досягнуто бажаного результату, в даному випадку - бажану психомоторику. Співвідношення між моторною командою, яка надається індивідом м'язам, і тими діями, які ми називаємо в результаті «рухом» - це так звана «трансформація тіла»; для успішного управління рухом ця трансформація має бути інвертована. Розлади у випадку оволодіння людиною трансформацією тіла $є$, як правило, розладами координації: різні м'язи не узгоджуються між собою в належному тимчасовому i/або силовому відношенні.

Отже, аналіз психологічних особливостей реабілітаційних заходів з фізичної реабілітації $є$ вельми актуальною проблемою, якою. Слід спеціально займатися. Тому метою нашої статті є: інсульті.

1. Описати соматичні розлади, які мають місце у випадку виконання рухів при ішемічному

2. Схарактеризувати розлади програмування управління психомоторною діяльністю.

3. Описати розлади координації виконання психомоторної діяльності.

4. Виокремити психологічні особливості корекції психомоторних розладів у хворих 3 ішемічним інсультом.

5. Запропонувати психологічні принципи формування загальних компенсаторних реакцій пацієнта у випадку проведення фізичної реабілітації хворих з ішемічним інсультом.

Результати теоретичного дослідження. Розлади, які мають місце у випадку виконання рухів при ішемічному інсульті, можна протиставити таким, які здійснюються за умов ініціювання рухів. Із функціональної точки зору будь-який рух починається аж ніяк не в ту мить, коли скорочуються або розслабляються будь-які м'язи. За допомогою фізіологічних і психологічних методів можна довести, передусім, наявність процесів підготовки до руху, які найчастіше називаються «запрограмовуванням»: сформована раніше рухова програма повинна бути напоготові і їі параметри слід пристосувати до необхідного руху. Розлади при цьому виявляються іноді лише при виконанні певної дії і тоді їх можна схарактеризувати як розлади цілеспрямованого управління програмою. Але, поряд 3 цим, існують розлади, які стосуються принципово іншої рухової програми, яка не була запрограмована індивідом. Довільному руху, зазвичай, передує відповідний намір або задум. 3 функціональної точки зору намір можна схарактеризувати як «правило ініціювання» [7, с. 103], яке пов'язує виклик психомоторної програми 3 критеріями даної дії (критеріями дії можуть бути: команда лікаря, інструктора і т.д.).

Далеко не завжди встановлення правил ініціювання дій супроводжується наміром здійснити певний рух. Правила ініціювання у людей $є$ досить гнучкими, але все ж таки виклик психомоторної програми може відбуватися з різною швидкістю і різним ступенем надійності. Дуже швидкий i 
надійний виклик здійснюється тоді, коли критерії дії відповідають просторовим або іншими ознаками інших, підпорядкованих першому рухів.

Програмування управління психомоторною діяльністю передбачає, що ця діяльність викликається мнемічними процесами. У разі розладів у психомоторній програмі можна очікувати, що пацієнт зможе виконати певний рух спонтанно, але не за вимогою лікаря. У таких пацієнтів відбувається репрезентація тих позицій, які мають бути прийнятими певною частиною тіла, безпосередньо виконує психомоторну діяльність тощо.

Опишемо розлади програмування управління психомоторною діяльністю. У науковій літературі (М. М. Кабанов [2, с. 5-15]) розрізняє програми управління психомоторною діяльністю і плани психомоторної діяльності. Відповідно до цієї термінології, програми управління психомоторною діяльністю - це стереотипна послідовність команд в центральній нервовій системі, які визначають порядок іннервації різних м'язів. Плани психомоторної діяльності координують кілька рухових програм і пристосовують їх до сучасних умов оточуючого середовища. Програма психомоторної діяльності передбачає чітку почерговість у фасилітації агоністів і антагоністів. Така послідовність м'язових активацій призводить до плавного, чітко спрямованого руху, що характеризується максимумом виконання швидкісних реакцій. Змінюючи тимчасові інтервали між активацією агоністів і антагоністів і модулюючи силу окремих м'язових активацій, можна досягти (в межах однієї і тієї ж рухової програми психомоторної діяльності) різну швидкість і амплітуду виконання цієї діяльності.

У більшості випадків виконання психомоторної діяльності, що є адекватною навколишньому світу, відбувається завдяки зору людини. Ця візуально-моторна координація рухів видається цілком зрозумілою і тривіальною. Однак, їі розвиток залежить від наявності певних умов і може бути дещо порушено. Удавана природність деяких функцій, таких як візуально-моторна координація, очевидно, означає не те, що система, яка реалізує ці функції, є доволі простою і здоровою, а лише те, що іiі активність не супроводжується свідомим переживанням виконання психомоторної діяльності.

Опишемо розлади координації виконання психомоторної діяльності. У реалізації певним чином цілеспрямованої психомоторної діяльності найчастіше бере участь м'язи, які повинні скорочуватися в певній послідовності і з певною інтенсивністю. При цьому можна говорити про деяку толерантність щодо помилок, тому що найчастіше один і той же результат руху може досягатися за рахунок різних патернів скорочення, але, природно, є й кордони, за межами яких психомоторна діяльність не вдається.

Бажаний результат виконання психомоторної діяльності залежить від певної форми іiї виконання. Координація м'язів, які скорочуються, в кінцевому підсумку здійснюється без будь-якої участі нашої свідомості. Тому можна стверджувати, що подібна система 3 багатьма компонентами, від яких слід очікувати досить точною спільну роботу, легко піддається розладам. Однією з простих форм розладу координації психомоторної діяльності може бути свого роду «надлишкова активність», коли замість чітко узгодженої спільної роботи різних м'язів великою мірою зростає м'язова напруга в цілому, і на цьому високому рівні цю напругу можна модулювати 3 великими труднощами у виконанні психомоторної діяльності.

Отже, в результаті чітко узгодженої взаємодії зазначених вище функціональних систем виникає той абсолютно індивідуальний рівень довільної моторики, який властивий кожному індивіду. Розлади в складних рухових системах, що виникають в результаті церебрального ішемічного інсульту, не може виявлятися в стереотипному психомоторному дефіциті, й практично завжди представлене складною і зовсім неоднозначною клінічної картиною.

Опишемо психологічні особливості корекції психомоторних розладів у хворих з ішемічним інсультом. Загальновідомим $\epsilon$ те, що однією 3 базових властивостей нервової системи $\epsilon$ іï пластичність, тобто, - здатність до утворення нових міжнейронних зв'язків у нервовій системі. Багатофункціональність мозкових утворень виявляється в здатності нейрофізіологічних систем кори і підкірки в нових специфічних умовах приймати на себе функції втрати дієздатності певних структур. Таким чином, у відповідь на альтернативне припинення регіонарного мозкового кровотоку центральна нервова система розвиває активну i, в більшості своїх акцій, - саногенерувальну діяльність. Здатність до відновлення втрачених в результаті пошкодження моторної кори функцій (локомоційні акти, цілеспрямовані рухи за допомогою руки (або обох рук) паралізованих людей в екстремальних життєво значущих ситуаціях) пов'язується 3 активізацією мотиваційних структур у психіці особистості. В даному випадку, мається на увазі наявність низького стартового бар'єру і вираженої мотивації в голографічній структурі головного мозку, яка постраждала в результаті інсульту, але зберегла цілісну інформацію в останніх відділах головного мозку. Голограмний характер трансформації навколишнього світу і стереотипних психомоторних реакцій дозволяє у 
великій кількості випадків зберегти адекватний психомоторний стереотип. За умов наявності більш серйозних обсягів уражень психомоторний стереотип адаптується протягом певного часу і потім зберігається в стабільному стані.

Адекватна тонусна реакція м'язової системи призводить до формування патологічного статичного стереотипу. Закономірності побудови психомоторного стереотипу засновані на розгальмованих вроджених рефлексах, але вони $\epsilon$ адаптивними за своїм характером і саногенетичні за своєю спрямованістю. 3 огляду на зроблений теоретичний аналіз наукової літератури запропонуємо психологічні принципи формування загальних компенсаторних реакцій пацієнта у випадку проведення фізичної реабілітації хворих з ішемічним інсультом:

1. Принщии актуалізаціï дефекту (зворотний зв'язок психомоторної дії, яка походить із різноманітних рецепторів, інформує інтегративні центри про існування певного дефекту).

2. Принци прогресивної мобілізації компенсаторних механізмів психомоторної діяльності (компенсація здійснюється із ступінчастим підключенням нервових систем до моменту досягнення лікарем необхідного ефекту).

3. Принцип безперервного зворотного концентрування компенсаторних механізмів психіки особистості (імпульсація щодо впливу дефекту надходить в центральну нервову систему безперервно).

4. Принци санкціонування компенсаторних механізмів психіки особистості (компенсаторні механізми починають працювати за умов досягнення патологічної імпульсації певного порогу).

5. Принцип відносної стійкості компенсаторних механізмів психіки особистості (компенсаторні механізми активізуються і пригальмовуються поступово).

У випадку ішемічних інсультів виявляється певна динаміка відновлення локусних розладів. Спочатку відновлюються рефлекторні функції і тонус, а потім з'являються психомоторні дії (глобальні і координаторні синкінезіі), а також допоміжні дії, i, нарешті, відновлюються довільні рухи. Для того, щоб почали відновлюватися сухожильні рефлекси і м'язовий тонус, необхідною $є$ нормалізація функцій спинного мозку.

Компенсація певних функцій, які мали розлади, заснована на перебудові старого стереотипу і на виробленні нового динамічного стереотипу. Важливим моментом компенсації структурнофункціональних розладів у випадку патології психомоторики $є$ активна участь в процесі реабілітації і самого хворого, який має прагнути активізувати системи організму, які зовсім не постраждали або постраждали несуттєво. Було показано, що за рахунок нових - які не постраждали - відділів центральної нервової системи можливою постає перебудова іннервації між антагоністами.Деякі вчені, зокрема Б.С.Віленський, М.М.Аносов [1] вказують на те, що відновлення психомоторних функцій відбувається, в основному, в перші 6 місяців після інсульту. Тим часом, пік відновлення доводиться на перші 2-3 місяці після інсульту. Одним із базових завдань реабілітаційних заходів для хворих з розладами психомоторних функцій є утримання рівноваги у вертикальному положенні і самостійне переміщення хворого. Неабияке значення цьому процесу надається і самими пацієнтами, що здобувають нову ступінь свободи в діях і новий соціальний статус, незалежний від сторонньої допомоги.

Завдання збереження стійкості тіла зводиться до того, щоб забезпечити утримання проекції загального центру ваги на опорну поверхню. 3 урахуванням біомеханічних особливостей вертикальної пози людини (мала площа опори, високе положення центра ваги, зростання статичних моментів в суглобах ніг в дистальному напрямку) можливими є такі ступені способи забезпечення стійкості [6]:

- $\quad$ стабілізація кутів в суглобах ніг (перш за все - гомілковостопних);

- $\quad$ стабілізація положення тулуба.

За умов ослаблення гальмівного диференційованого впливу кори головного мозку відбувається відновлення керуючого впливу на рухову сферу зі структур вестибулярно-мозкового комплексу, які виявляються в одночасному впливі на формування патологічного рухового стереотипу тонічних рефлексів: лабіринтового тонічного рефлексу, симетричного шийного тонічного рефлексу, асиметричного шийного тонічного рефлексу, хапальних рефлексів, рефлексів з голови на тулуб і 3 таза на тулуб тощо (81). При цьому, слід зазначити, що різноманітність змін рухового стереотипу в позі Верніке-Манна, на наше стійке переконання, визначається локалізацією і розміром осередку ураження. Так само має місце суттєве посилення патологічних анти-гравітаційних реакцій при переході пацієнта з горизонтального положення у вертикальне.

При цьому незалежно від рівня розладів, картина розладів психомоторної функції підпорядковується певним біомеханічних законам:

1. Правило перерозподілу функиій ураженої кіниівки.

Випуск 12, 2019. Збірник наукових праць РДГУ 
Функціональні можливості ураженої кінцівки підтримувати вагу тіла значно знижуються. Це особливо помітно в період одиночної опори: зменшується як абсолютне, так і відносне за часовими інтервалами функції одиночної опори, а також тривалість періоду опори. Але такого роду розвантаження хворої сторони має бути компенсована, адже період опори здорової ноги суттєво збільшується. Зміна періодів опори має очевидний наслідок - збільшення на хворому боці часу перенесення, на здоровій - ії скорочення. Правило перерозподілу функцій полягає в тому, що здорова кінцівка виконує переважно функції опори, а хвора - переважно функцію перенесення.

2. Правило функиіонального копіювання рухів іншої особи.

Патологічна асиметрія не вигідна організму ні 3 точки зору енергетики, ні механіки. Необхідність підтримувати відносну симетричність функції правої і лівої сторін тіла призводить до наступного висновку: здорова сторона тіла (або кінцівка) має неабиякий функціональний резерв, аніж хвора, тому зменшення функціональної асиметрії відбувається шляхом наближення зразка функціонування здорової кінцівки до зразка хворий.

Правило функціонального копіювання рухів іншої особи полягає також і в тому, що здорова кінцівка копіює функцію хворої з метою нівелювання функціональної асиметрії.

3. Правило забезпечення оптимуму в психомоторній діяльності.

Функціонування всіх елементів нормального циклу психомоторної діяльності є основою фізіологічної оптимальності індивіда. Будь-які відхилення від фізіологічної оптимальності вимагають включення додаткових адаптивних резервів, які на ураженій стороні дещо змінені. Забезпечити хворому оптимальність функціонування можна за рахунок функціональної напруги здорової сторони.

Правило забезпечення оптимуму полягає, передусім, в тому, що хворій кінцівці забезпечується такий режим функціонування, який значно наближений до норми за рахунок функціонального напруження здорової кінцівки.

Висновки та перспективи подальшого дослідження. Таким чином, дослідження структури i закономірностей патологічної ходьби свідчить про те, що за умов наявності патології людина дотримується одного і того ж принципу організації роботи м'язів-антагоністів, які на даний період часу функціонують за нормою. Згідно з цим принципом м'язи-розгиначі виконують в основному силову функцію, в той час як діяльність м'язів- згиначів набуває переважно корекційного характеру. I це взаємовідношення у випадку будь-якої іншої патології також не порушується. Спільна участь м'язів-розгиначів і м'язів-згиначів в компенсаторних умовах при патологічній ходьбі в умовах переміщення центру ваги ще не свідчать про втрату відмінностей між їх інерваційними програмами. Навпаки, в умовах значного огрубіння локомоторного акту ці відмінності виявляються більш значущими: позначається огрубіння м'язів протягом психомоторного циклу, одночасне збудження м'язів-розгиначів, велика варіабельність фаз активності м'язів-згиначів.

М'язи протягом локомоторного циклу нормальної ходьби працюють інколи в поступальному, то в акти візуальному режимі. Тривалість режимів визначається межами біомеханічних фаз. Поступальний режим в нормі домінує в роботі м'язів-розгиначів, тоді як в діяльності м'язів-згиначів обидва режими представлені приблизно однаково. В цілому, ходьба хворих 3 геміпарезом характеризується: уповільнення темпом здійснення психомоторної діяльності; невеликою довжиною кроку; низькою швидкістю психомоторної діяльності; зміною локомоторного циклу нормальної ходьби. Більш докладно розлади довільних рухів при ішемічному інсульті та психологічні особливості фізичної реабілітації пацієнтів з цією хворобою будуть проаналізовані у наступних наших публікаціях.

\section{Список використаних джерел}

1. Виленский Б. С. Инсульт - трудности и ошибки при диагностике и лечении / Б. С. Виленский, Н. Н. Аносов. - Л. : Медицина, 1980. - 143 с.

2. Кабанов М. М. Концепция реабилитации - ведущее направление научной деятельности психоневрологического института им. В. М. Бехтерева / М. М. Кабанов // Восстановительная терапия и реабилитация больных с нервными и психическими заболеваниями. - Л. : Медицина, 1982. - С. 5 15.

3. Фармацевтична енциклопедія [Електронний ресурс]. - Режим доступу : https://www.google.com/url.

4. Kurlan R. Treatment of Movement Disorders / R. Kurlan. - Philadelphia : Lippincott, 1995. - 190

p.

5. Perrenon D. A. Biased postural vertical in humans with hemispheric cerebral lisions / D. A. Perrenon, B. Amblard, C. Leblond // Neurosch. Lett. - 1998. - V. 14. - P. 75-78.

6. Rusk H. A. Rehabilitation medicine / H. A. Rusk // Ed. by S.T. Louis. - 1958. - 572 p.

Випуск 12, 2019 Збірник наукових праць РДГУ. 
7. Sanes J. N. Motor control in humans with large-fibre sensory neuropathy / J. N. Sanes, K. H. Mauritz, M. S. Dalakas // Human Neurobiology. - 1985. - P. 101-114.

\section{References}

1. Vilenskij B. S. Insul't - trudnosti i oshibki pri diagnostike i lechenii / B. S. Vilenskij, N. N. Anosov. - L. : Medicina, 1980. - 143 s.

2. Kabanov M. M. Koncepciya reabilitacii - vedushhee napravlenie nauchnoj deyatel'nosti psixonevrologicheskogo instituta im. V. M. Bextereva / M. M. Kabanov // Vosstanovitel'naya terapiya i reabilitaciya bol'nyx s nervnymi i psixicheskimi zabolevaniyami. - L. : Medicina, 1982. - S. 5-15.

3. Farmatsevtychna entsyklopediia [Elektronnyi resurs]. - Rezhym dostupu : https://www.google.com/url.

4. Kurlan R. Treatment of Movement Disorders / R. Kurlan. - Philadelphia : Lippincott, 1995. - 190

p.

5. Perrenon D. A. Biased postural vertical in humans with hemispheric cerebral lisions / D. A. Perrenon, B. Amblard, C. Leblond // Neurosch. Lett. - 1998. - V. 14. - P. 75-78.

6. Rusk H. A. Rehabilitation medicine / H. A. Rusk // Ed. by S.T. Louis. - 1958. -572 p.

7. Sanes J. N. Motor control in humans with large-fibre sensory neuropathy / J. N. Sanes, K. H. Mauritz, M. S. Dalakas // Human Neurobiology. - 1985. - P. 101-114.

\section{N. O. Mykhalchuk, L. L. Prymachok PSYCHOLOGICAL PECULIARITIES OF CORRECTION OF PSYCHOMOTRIC DISORDERS OF PATIENTS WITH ISCHEMIC STROKE}

The article deals with somatic disorders that occur in a case of ischemic stroke; programming disorders of psychomotor activity of patients were described; disorders of coordination of presenting of psychomotor activity by patients were described; the psychological peculiarities of correction of psychomotor disorders of patients with ischemic stroke were singled out. The most frequent and severe consequence of cerebral ischemic stroke is the disorder of the motor functions of the person. Characteristic feather is the polymorphism of motor disorders of patients with cerebral ischemic stroke. In this case, general for patients is only the loss or violation of arbitrary actions (in the cases of hemiparesis or hemiplezia). Other clinical symptoms are largely variable and depend on a certain extent of the size of affected area, also its localization. According to various authors, persistent disturbances of motor function are also observed in the first days after the disease (in 70-80\% of cases of patients who had the ischemic stroke).

Motor disorders can be distinguished (by the type of their genesis) on primary-organic and psychogenic motor disorders. In the case of primary-organic motor disorders pathological changes are observed in the muscular, skeletal or nervous systems, however, in the conditions of psychogenic motor disorders the presence of such changes proved to be objectively impossible. To describe motor disorders of a patient, first of all, it is necessary to know: a) what functions must be distinguished in the cases of the process of motor regulation of a person; $b$ ) in what forms the disorders of these functions are revealed. The main differences observed between disorders are: a) initiation of actions; $b$ ) frustration in their presentation. In the cases of doing the actions there are disorders of the programmed control, regulation and coordination. Disorders that occur in the case of actions in a case of ischemic stroke can be compared with so called «initiated actions». From the functional point of view any action does not start at the moment when any muscles are reduced or relaxed. With the help of physiological and psychological methods it can be proved first of all, that there are processes of preparation for actions, which are often called "programming ones»: the previously formed motion program must be ready and its parameters should be adapted to required action. Such kind of disorder appears sometimes only in a case of performance of certain action and then they can be described as disturbances of purposeful management of the program of a patient. But, according to this, there are disorders that relate to a fundamentally different motor programs which have not be programmed by the person.

Psychological principles of the development of general compensatory reactions of the patient in a case of physical rehabilitation of patients with ischemic stroke were proposed in this research. These principles are: 1) the principle of actualization of the defect; 2) the principle of progressive mobilization of compensatory mechanisms of psychomotor activity; 3) the principle of continuous reverse of concentration of compensatory mechanisms of the psyche of the person; 4) the principle of sanctioning compensatory mechanisms of the psyche of the person; 5) the principle of relative stability of the compensatory mechanisms of the psyche of the patient.

Key words: physical rehabilitation, ischemic stroke, management of psychomotor activity, compensatory reactions, compensatory mechanisms, correction of psychomotor disorders.

Випуск 12, 2019. Збірник наукових праць РДГУ 